\title{
One Nation Conservatism and social policy, 1951-64
}

One Nation Conservatism is sometimes portrayed as a key part of a perceived post-war 'consensus' between the main political parties on economic and social policy issues, epitomised for many by the term 'Buskellism', an amalgam of the names of R. A. Butler (Conservative Chancellor of the Exchequer, 1951-5) and Hugh Gaitskell (Labour Chancellor, 1950-1 and Shadow Chancellor, 1951-5), used to describe the general acceptance of Keynesian economics and demand management of the economy (for example, Howard, 1987). This branch of Conservatism has often sought to identify its ideas with those of Disraeli and his concern with the social divisions (or 'two nations') associated with industrialisation identified in his novel Sybil, and has been linked with Baldwin in the 1920s, who drew on Disraeli's ideas but spoke of 'One Nation' (Tyrie, 2006) as part of his arguments for a moderate and inclusive form of Conservatism (Walsha, 2003). However, it was arguably only in the post war period, with the emergence and activities of the One Nation Group of Conservative MPs, that One Nation Conservatism became of particular importance as a strand of Conservative thinking. This article considers the nature of One Nation Conservatism in the period from 1951 to 1964 through an examination of the One Nation Group, its key publications, and the policies pursued by the Conservative governments of the time. It suggests that the link between the One Nation Group and Conservative policies may not be as clear as is sometimes implied, and that it was the combination of a somewhat more positive and pragmatic approach to the welfare state, and the economic growth of the period, rather than any new and significant commitment to social justice and tackling poverty, that have helped shape perceptions of One Nation Conservatism over the past fifty years.

\section{The One Nation Group}

Even before Labour's 1945 election victory the paternalistic tradition and the pragmatic nature of much Conservative thinking meant that the Conservative Party was willing to support state intervention in welfare to ameliorate social disadvantage, particularly where this was seen as appropriate to develop or protect Britain's economic interest or development. The Baldwin government of 1924 to 1929 had the avowed objective of reconciling the bitter differences in the country and did introduce reforms driven in large part by Neville Chamberlain, such as improvements in unemployment and health insurance, the extension of old age pensions, and the encouragement of local authorities to develop hospital provision. But at the same time, unemployment remained high, particularly in areas where coal, heavy industry and textiles were suffering from a loss of their export markets, and there was extensive use of means-testing.

During the Second World War Churchill's Conservative-led coalition government introduced the 1944 Education Act, with the intention of improving educational opportunities for all, the 1945 Family Allowances Act, and published plans for major improvements in health care and social security. During the 1945 general election campaign they retained a generally positive approach to social and economic intervention including a commitment to high levels of employment, and promises to build at least 220,000 homes in the first two years in office, to develop a compulsory National Insurance scheme, and to create a comprehensive health service with no one excluded from treatment because of an inability to pay. 
Following Labour's election victory some more progressive Conservatives called for a clearer statement of principles for the Party in the post-war era, and in particular for support for the 'One Nation' vision as a way forward. Such demands were arguably reflected in the publication of The industrial charter (Conservative and Unionist Central Office, 1947), which, while reaffirming the Party's commitment to free enterprise, also said that the Party would seek cordial relations with the trade unions and maintain a level of demand which would offer jobs to all who were willing to work. In the run-up to the 1950 election The right road for Britain (Conservative and Unionist Central Office, 1949), while stressing the need for efficient industrial production, 'good housekeeping' and the need to curb public expenditure, also spoke of unemployment as a 'heavy and growing danger' (p. 15), stated that the Party was sympathetic to Labour's welfare reforms, such as National Health Service, family allowances and national assistance, and said that the Conservatives would continue to 'maintain the range and scope of these Services, and the rates of benefit' (p. 42).

Following the Conservatives' 1950 general election defeat, nine newly-elected backbench MPs, including Edward Heath, Iain Macleod, Angus Maude and Enoch Powell, formed the One Nation Group, the publications and ideas of which have frequently been seen as underpinning the Conservatives' approach to social policy through the 1950s and into the 1960s. The apparent influence of the group was perhaps reinforced by the number of its members who were promoted to the ministerial ranks, a pattern that continued with later recruits such as Keith Joseph, Reginald Maudling and Geoffrey Rippon.

\section{One Nation Group publications}

The One Nation Group produced a series of pamphlets during this period which aimed to set out a vision for post-war Conservative policy. The first, One nation: a Tory approach to social problems (Conservative Political Centre, 1950), was intended to help develop a distinctively Conservative approach to social policy (Walsha, 2000). It highlighted a 'fundamental disagreement' (p. 9) between Conservative and Labour approaches to social policy, emphasising that the Conservatives would prioritise economic stability, administrative efficiency, selectivity and a minimal level of services, contrasting these with what they saw as Labour's commitment to egalitarian social expenditure, universalism and optimal levels of provision, and suggesting that in relation to the redistribution of wealth the economic and social optimums had been passed and that the future well-being of the poorest and the social well-being of the nation were being endangered by the effects of redistribution. It reinforced arguments for traditional Conservative concerns, such as industrial efficiency, low taxation, a stable currency, self-reliance, voluntarism and charitable activities, whilst at the same time suggesting that positive support for state intervention would complement, rather than challenge, the progressive role of the market. It also argued that the state should provide a 'minimum standard, above which people should be free to rise as far as their industry, their thrift, their ability or their genius may take them' (p. 9). And whilst it criticised many aspects of Labour's approach it stated that 'Social reform is not an exact science, nor is there an end to it. If no dramatic advance is possible for some years - and the urgent claims of Defence are certain to prevent it - there is still the not less important administrative task of making the Welfare State work' (p. 16). The pamphlet argued that there was a need to prioritise, and that housing and education should be the main priorities, with the building of new homes and other emergency measures being necessary to reduce homelessness and improve standards of health, and the provision of primary education and then technical schools and colleges being key to an industrial nation, whilst it proposed restraint in relation to social security benefits and pensions. The authors argued for a "principle of the guaranteed standard of life and 
security, below which none shall be allowed to fall' (p. 73) being the main purpose of state provision and that the government should be responsible for maintaining full employment.

Two years after the publication of One nation, two of its authors, Macleod and Powell, produced The social services: needs and means (Macleod and Powell, 1952). In this pamphlet they argued that high taxes were a disincentive to work and that the growth of the welfare state was leading to a decline in individual initiative and in family responsibility and questioned the provision of welfare without a means test. They also suggested that social policy was moving too far from the contributory and insurance principle, with social security and the National Health Service being based too much on expenditure from general taxation, and argued both for the NHS to be financed on an insurance basis and for the reintroduction of charging as a means of finance. The pamphlet argued that 'Given that redistribution is a characteristic of the social services, the general presumption must be that they will be rendered only on evidence of need, i.e. of financial inability to provide each particular service out of one's own or one's family's resources' (p. 5) and that this was inappropriate so that 'The question which therefore poses itself is not, "Should a means test be applied to a social service?" but "Why should any service be provided without a test of need?"' (Macleod and Powell, 1952, p. 5). However, Macleod and Powell also argued that where services provide a 'public and general benefit' (p. 7), as they suggested was the case with education, although not the health service, then it should be provided free of charge.

Another One Nation group publication, Change is our ally (Powell and Maude, 1954) questioned the role of government in the economy and central planning, and argued for a greater emphasis upon market forces, with more competition and risk-taking and investment predominantly by the private sector, rather than governments. This increasing emphasis on the free market may reflect Powell's growing influence on the Group (Walsha, 2000). The introduction to the pamphlet did, however, argue 'To the Tory the nation is not primarily an economic entity. It may place political and social ends above economic ones, and for their sake may justifiably on occasion seek to prevent change or divert it' (Powell and Maude, 1954, p. 7).

In 1959 the One Nation group produced The responsible society (Conservative Political Centre, 1959), which argued that such a society could never be achieved on the basis of state action alone, but must look to 'the satisfaction of religious belief and action, and to the fulfilment of the social responsibilities which rest on all its members, individually, as families, and in other groupings' (p. 9). Ideas of voluntarism, individualism and self-reliance were recurring themes. Yet, whilst favouring lower levels of taxation and individual's providing for themselves, the pamphlet nevertheless stated that 'The social services for the most part are here to stay: in an increasingly complex society they have come to provide a minimal framework of amenity' (p. 31) and that 'The Welfare State, combined with full employment and high earnings, has added to the freedom of the citizen' (p. 34). However, for services such as health and pensions, the pamphlet supported a shift from payment through taxation to payment by contributions. It also noted the perceived political reality that 'Successive general elections have been fought on the understanding that the Party which does most for the social services will fare best' (p. 33).

This series of pamphlets perhaps serves to illustrate that an attempt to identify the key principles of One Nation Conservatism is not straightforward, even when restricted to the One Nation Group itself. From its early days the Group itself comprised individuals with varied political views, and perhaps not surprisingly, the ideas put forward in their 
publications also varied. In reality, in the most significant publication, One nation, there was relatively little which had not already been foreshadowed in official party statements, including The right road for Britain. In terms of ideas and policy proposals One nation clearly drew on traditional Conservative concerns but it also sought to react to the perceived new reality of the post war years, including the welfare state, even if these were presented as part of gradual creation of 'The social service state' (p. 14) by 'Conservative, Liberal, Coalition and Socialist Governments' (p. 15). Whilst the One Nation group opposed equality as a political principle (Hickson, 2005) and wished to check the growth of collectivism and encourage greater choice in social policy, they did not therefore recommend any immediate radical changes in the structure of the post war settlement. What the publication of One nation did do was to provide a broad rationale for the Conservatives' approach to social policy based upon the idea that whilst the state had grown too big and taken on responsibilities better undertaken by citizens and civil society, there was nevertheless a case for state intervention in appropriate areas of economic and social life and particularly in ensuring minimum standards in social provision, whilst at the same time arguing for a shift towards individual effort and achievement. In doing this it supported the view that the Party had responded to the new demands of the post-war period. Its reception, including selling 8,500 copies (Walsha, 2000), also reinforced the view of the One Nation Group as a significant influence upon the Party's leaders.

However, perhaps more entrenched and less pragmatic right-wing opposition to big government and the welfare state was clear in the writings of scholars such as Hayek (1944, 1960), Lees (1961) and Seldon (1961), and in the creation of the Institute of Economic Affairs in 1957, followed by other right-wing 'think tanks' which were committed to free market economics and the rolling back of the state. In addition, whilst the ideas of the One Nation Group have perhaps generally been associated with a progressive Conservatism in keeping with the approaches of individuals such as Butler, Eden and Macmillan, arguments such as those for retrenchment of taxation and means-testing have also been traced through to Thatcherism. The reality is that both views have some truth, and indeed are not necessarily incompatible, given that the Group's publications reflected the context of the time and the often varying and competing views of a range of individuals.

\section{Conservative social policy 1951-64}

Any examination of the Conservative Party's general election manifestos from the period makes clear the general acceptance of, or at least an unwillingness to express opposition to, most aspects of the welfare state. Whilst emphasising traditional Conservative themes such as taxation and freedom, the 1951 manifesto highlighted the need for new homes, albeit with a preference for owner occupation, and promised to make better use of the money being spent on education and health, and to help those pensioners in the greatest need. Similarly the 1955 manifesto stressed the need for an efficient and productive economy, and a desire for lower taxes, but also emphasised full employment, slum clearance and investment in education, as well as a desire for 'the best National Health Service the country can afford'. In 1959 the Conservatives noted the success of the preceding governments in providing 'over two million new homes and almost two million new school places, a better health service and a modern pensions plan', and whilst the manifesto promised to defend grammar schools it also undertook to bring modern schools up to the same high standard, to continue programmes of house and hospital building and to 'ensure that those dependent on national assistance have a 
share in the country's increasing prosperity'. Even in 1964 the manifesto continued to stress full employment, educational expansion and improvements to hospital and housing stock.

Following a narrow general election victory in 1951 the Conservatives' commitment to the welfare state was tested when the government was faced with a significant balance of payments deficit. The new Chancellor, R. A. Butler, decided to reduce imports, tighten monetary policy and review public expenditure commitments. However, despite some changes to welfare expenditure, such as the introduction of some charges for the NHS, and a reduction in the building programme for schools, there were no draconian cuts in the welfare budget. Indeed, whilst the concerns over public expenditure which led to the establishment of the Phillips Committee (1953) on the Economic and Financial Problems of Provision for Old Age and the Guillebaud Committee (1956) into the Cost of the National Health Service, were perhaps indicative of the Conservatives' general approach to welfare, there was no attempt to dismantle the welfare state that had been created by the Attlee government. Whilst the Phillips Committee recommended that government should abandon any attempt to raise retirement pensions to subsistence level because of the burden it would place on public finances, the Guillebaud report found that the NHS was well run and effective and that there was no evidence of extravagant spending, and made recognised that rather than cuts in expenditure there would be a need for increases in the future. At this time, in addition to Butler as Chancellor, the appointment of more progressive ministers in areas such as education (Eccles, 1954-7) and health (Iain Macleod, 1952-5) appeared to further establish One Nation thinking within the Party. During this government it could therefore be argued that something of a distinctive 'One Nation' approach to state welfare was emerging, with an emphasis upon targeting, restraints on expenditure and greater use of charging.

Following further victories in the 1955 and 1959 general elections and under the leadership of Anthony Eden (1955-7), Harold Macmillan (1957-1963) and Alec Douglas-Home (1963-4) the Conservatives continued to pursue a broadly One Nation approach, seeking to balance traditional Conservative economic concerns, such as low taxation and price stability, with social concerns such as the maintenance of full employment and broad support for the welfare state. However, this was not always straightforward, and in the mid-1950s as economic growth slowed, in an attempt to prevent tax increases immediately following the 1955 general election the Treasury reviewed the prospects for social expenditure, noting the rising costs of education from the growing school population as a result of the post war growth in the birth rate and that pensioners would start to earn rights to a pension under the post-war scheme. In response the spending departments mounted an organised opposition, arguing, for example, that some parts of social expenditure had economic benefits. Following continuing concerns within the Treasury about the growing costs of welfare provision, in January 1958 the Chancellor, Peter Thorneycroft, and two cabinet colleagues (Enoch Powell and Nigel Birch), resigned after the Cabinet refused to agree a request for $£ 153$ million cuts in welfare expenditure that were intended to help reduce inflation and restore international confidence in sterling. In 1961 another sterling crisis saw the Treasury again seeking cuts in social spending, whilst around the same time an internal Conservative Party review suggested that policies such as the withdrawal of the universal state pension and the introduction of fees for state schools would help restrain the growth of welfare spending. Although such changes were arguably too radical for the Party's leadership of the time, a range of more modest measures were introduced with the aim of cutting welfare spending, such as increased health and social security contributions and higher rents for council tenants.

\section{Housing}


Following the Second World War the Labour government had prioritised local councils as the main source of new housing but many Conservatives favoured private building for owner occupation. One nation had argued that 'Housing is the first of the social services' (p. 10) and argued that the volume of housing build by the private sector should be increased and that rent controls should be reformed. The Party set itself a target of building 300,000 houses a year at the 1950 Party Conference, and repeated this in the 1951 manifesto, but with a much greater emphasis than Labour on private sector construction, private landlords and renting, and owner occupation. However, the 300,000 figure could not be met by the private sector in the short term and there was therefore a need for more public expenditure on the building of council homes. But the Conservatives tightened the controls and design limits, aiming to provide a cheap and plentiful form of housing, whilst approvals for the proportion of houses with three or more bedrooms was reduced significantly, from four-fifths under the Labour government to two-fifths by the end of the 1950s. This period saw owner occupation and local authority tenancy grow, together with a major decline in the private rented sector, accelerated from the mid-1950s by slum clearance, which itself reinforced the view of many that private landlords had 'failed' (Green, 2002). In an attempt to revive the private rental market the government reduced the control of rents through the 1957 Rent Act, but one of the main results of this was to enable landlords to evict people and sell properties that had previously been let into owner occupation (Hill, 1983). From the mid-1950s there was a desire to maintain the mixed economy of housing provision so that subsidies for the building of council homes were reduced and there was increased pressure on local authorities to sell council homes, including through the provision of mortgages (Lowe, 1993). However, the private rental market continued to be seen as problem and the Housing Act 1961 allowed landlords to raise rents only after improving their properties.

\section{Education}

As noted above, both One nation and The social services: needs and means had emphasised the importance of education, with the former even arguing that so long as the Cold War continued 'Education is more than a social service; it is part of Defence' (p. 39). Given the Conservatives' part in the passage of the Butler Act it is perhaps unsurprising that in general this period saw an increase in the resources available for state education. The post-war 'baby boom' meant that there was in any case a need for more schools and teachers, but a series of reports (for example, Central Advisory Council for Education, 1954, 1959; Robbins, 1963) arguably both highlighted the importance of education and influenced policy development. The Education Act 1944 had laid the foundations for a system of secondary education grounded in the idea of selection through the '11-plus' examination, with some children progressing to grammar schools and others to secondary moderns, and in some places technical schools. However, during the 1950s a number of local authorities began to introduce an alternative model, comprehensive schools, but the Conservative Party, including in its general election manifestos in 1955 and 1959 manifestos promised to defend and develop grammar schools. Following the White Paper Secondary education for all (Ministry of Education, 1958) a major school building programme took place, albeit mainly of secondary moderns. Within higher education, university colleges such as Sheffield and Southampton were upgraded to university status, and even before the publication of the Robbins report approval was given for seven new universities, including East Anglia, Lancaster, Warwick and York.

\section{Health}


The NHS rapidly proved to be popular with the British public, meaning that whilst the Conservatives may have disliked its universalist construction and its funding from general taxation, and had favoured the retention of the voluntary hospitals and the encouragement of the private sector, they found it difficult to attack. It was also an area where the views of the One Nation Group appeared to vary, so that whilst One nation was generally supportive of the NHS, in The social services Macleod and Powell called for a shift away from taxation towards insurance and charging to finance the service, and The responsible society also argued for a shift from tax towards contributions.

In reality, there was little major change in health policy, although in June 1952 prescription charges, which had been legislated for but not implemented under the Labour government, were introduced, at the rate of one shilling ( $5 p)$ per form, and these were followed by charges for false teeth and for glasses. In addition, capital expenditure was kept under tight control and there was effectively a freeze on staffing. The one major piece of legislation during this period was the Mental Health Act 1959, which abolished the 'certification' procedure for the compulsory admission of people to hospitals, and together with advances in treatment, reduced both the use of compulsory procedures and the incidence of long stays in psychiatric hospitals. By the early 1960s the poor state of much hospital provision led to pressure for change and the development of the 1962 Hospital Plan, which aimed to provide modern and comprehensive facilities based upon a network of district general hospitals, although this was arguably not to be a great success (Lowe, 1993).

\section{Social security}

While there were few major changes to social security provision under the Conservative governments of the 1950s and 1960s, there were developments that indicated the ongoing tensions within the Party, and which indeed reflected those within the One Nation Group's publications. For example, there was some increase in support within the Conservative Party for greater selectivity and use of means-tested benefits, enabling Labour to refer to 'two nations', one with earnings-related benefits, the other relying on Beveridge's flat-rate benefits (George, 1968). In addition, whilst there was a widespread belief at the time that social and economic policies adopted in the 1940s and 1950s were having egalitarian and redistributional effects, Titmuss and others were producing evidence that inequalities of income and wealth were instead growing, with Titmuss (1962) noting the decline of the progressive tax system and the greater use of indirect taxes and suggesting that this 'may mean in the long run a gradual abandonment of the search for equity' (p. 197). This, and the 'rediscovery' of poverty in a number of academic works in the early 1960s did lead to some reappraisal by the political parties of policies aimed at relieving poverty, but the Conservatives' manifestos for the 1955, 1959 and 1964 general elections almost completely neglected such issues and any immediate attempt to respond to these was left to the Labour governments of 1964-70.

In terms of policy, in 1952 the government reduced the level of the food subsidy, which had been in place since the war, although in the same year family allowances were increased, including to help minimise the possible impacts on nutrition, and in 1956 the allowance was extended to all school children. The government was, however, anxious to make economies, and the bread subsidy was abolished. Nevertheless, family allowances remained a contentious area, and were one of the areas proposed for cuts by Peter Thorneycroft in 1957, prior to his resignation. Indeed the differing pressures on social security during the period are evident in 
Cabinet papers from the 1950s and 1960s which show concerns over recommendations for increases made by the National Assistance Board, and in some cases differences of opinion between ministers responsible for pensions and national insurance, and the Chancellor of the Exchequer who was seeking to contain increases in public expenditure.

By the mid-1950s there were concerns within both of the major parties about problems with the National Insurance system and with Labour proposing a graduated but redistributive system of graduated but redistributive system the Conservatives felt pressured to respond. Whilst some Conservatives, such as Boyd-Carpenter and MacLeod, sought to develop a scheme not solely for economic efficiency but also on the basis of social justice, others, including in the Treasury, wished to see a reduction in the cost to the Exchequer of National Insurance (Bridgen, 2000). Eventually, the reformers, despite the initial support of Macmillan, lost out, and in 1959 a limited graduated pension scheme was introduced as a 'top-up' to the flat rate system (Bridgen, 2000; Hill, 1983), although contributors were able to 'contract out' of the state scheme and instead choose an approved tax-subsidised occupational pension provided by insurance companies (Lowe, 1993), with an increasing number choosing to do so during the $1960 \mathrm{~s}$.

\section{The personal social services}

Under the Conservative governments Children's departments continued to develop and extended their activities into work designed to play a greater role in preventing child abuse and neglect, and the Children and Young Persons Act 1963 helped to legitimise and encourage such changes in emphasis. The activities of other local authority welfare services also continued to develop, including responding to the need to replace the poor law inheritance of former workhouses and replace them with smaller, more appropriate, accommodation for older people and disabled people.

\section{Conclusions}

The writings of the One Nation Group should perhaps be seen very much as artefacts of their time, and as responding to the expectations and realities of post-war period, including the need for economic reconstruction and the popularity of many parts of the welfare state. In addition, the pamphlets were written and edited by different individuals, and there was not always agreement among them. Indeed, Walsha (2003) argues that the range of attitudes amongst members of the One Nation Group has always been less uniform than has been widely assumed, that the group's pamphlets, including those of the 1950s, largely 'offer snapshots of policies members were agreed on at sporadic junctures' (p. 78) and that the influence of the group in the 1950s and 1960s might have been exaggerated by the perception that any adoption of policies and practices that appeared to 'accord to the aims and principles of One Nation Conservatism were frequently translated as a victory for the One Nation Group, regardless of its actual level of involvement' (p. 81).

As noted earlier in this article, in many respects there was not as much new in the One Nation Group's proposals as is sometimes suggested, and arguably the greatest significance of the Group, and in particular One nation, was to provide a more coherent and persuasive underpinning for Conservative social policies, 'the sense of a programme, where previously there had been disparate policies' (Walsha, 2003, p. 85). 
What is clear is that following the Conservatives election victory in 1951 they left the basic structures of the welfare state unchanged. Under Butler as Chancellor from 1951 to 1956 the share of GDP which went on education, health and social security remained fairly steady, at around eleven per cent (Glennerster, 2007). However, this was in part because the world and British economies were enjoying a post-war boom and this in turn helped distract demands for more fundamental changes in public expenditure, including on social policy. Even with slower economic growth in the 1950s and calls from the Treasury for reductions in social expenditure, the spending departments and their supporters were largely successful in opposing this, and under Macmillan's premiership, from 1957 to 1963, the Conservatives retained a largely corporatist approach to planning, a commitment to full employment, incomes policy and social welfare.

It is not unreasonable to conclude that from 1951 to 1964 One Nation Conservatism, and any consensus, endured because of a combination of factors: firstly, many parts of the welfare state were clearly popular with the public and attempts to reduce them would have held electoral dangers; secondly, successive Conservative leaders - Churchill, Eden, Macmillan and Home - held broadly similar views of the role of government and believed that Britain should be governed from the political centre; and perhaps most importantly, the policies and approaches of the period appeared to be delivering prosperity for the public and electoral success for the Conservative Party. Whilst these coincided with the views of a group of more progressive Conservatives, some of whom rose to ministerial positions at this time, ideas which placed much greater emphasis on individual responsibility, lower taxation and a smaller role for government continued to be a significant part of Conservative thinking, and were perhaps encouraged by the recurring economic crises. In 1961 Macmillan noted in his diary the division in the Cabinet between the dirigistes, including himself, and those who favoured liberal, laissez faire, views (Macmillan, 1973). When Macmillan resigned as Prime Minister on health grounds in 1963, and with the Conservative Party's defeat under Alec Douglas-Home at the 1964 general election, the strength of the One Nation strand within the Party was arguably in decline and the door open for the growing influence of New Right thinking. 


\section{References}

Bridgen, P. (2000) 'The One Nation Idea and State Welfare: The Conservatives and Pensions in the 1950s', Contemporary British History, 14 (3): 83-104.

Central Advisory Council for Education (1954) Early leaving, London: HMSO.

Central Advisory Council for Education (1959) Fifteen to eighteen, London: HMSO.

Conservative and Unionist Central Office (1947) The industrial charter, London: HMSO.

Conservative and Unionist Central Office (1949) The right road for Britain, London:

Conservative and Unionist Central Office.

Conservative Political Centre (1950) One nation: A Tory approach to social problems, London: Conservative Political Centre.

George, V. (1968) Social security: Beveridge and after, London: Routledge and Kegan Paul.

Glennerster, H. (2007) British social policy: 1945 to the present, Oxford: Blackwell.

Green, E. (2002) Ideologies of Conservatism, Oxford: Oxford University Press.

Guillebaud Committee (1956) Report of the Committee of Enquiry into the Cost of the National Health Service, London: HMSO

Hayek, F.A. (1944) The road to serfdom, London: Routledge and Kegan Paul.

Hayek, F.A. (1960) The constitution of liberty, London: Routledge and Kegan Paul.

Hickson, H. (2005) The political thought of the Conservative Party since 1945, Basingstoke: Palgrave Macmillan.

Hill, M. (1983) Understanding social policy, Oxford: Basil Blackwell.

Howard, A. (1987) RAB - The life of R. A. Butler, London: Jonathan Cope.

Lees, D.S. (1961) Health through choice, London: Institute of Economic Affairs.

Lowe, R. (1993) The welfare state in Britain since 1945, Basingstoke: Macmillan.

Macleod, I. and Powell, J.E. (1952) The social services - needs and means, London:

Conservative Political Centre.

Macmillan, H. (1973) At the end of the day, London: Macmillan.

Ministry of Education (1958) Secondary education for all, London: HMSO.

One Nation Group (1959) The responsible society, London: Conservative Political Centre. 
Phillips Committee (1953) Report of the committee on the economic and financial problems of old age, London: HMSO.

Powell, E. and Maude, A. (eds) Change is our ally, London: Conservative Political Centre.

Robbins Committee on Higher Education (1963) Higher education, London: HMSO.

Seldon, A. (ed) (1961) Agenda for a free society, London: Institute of Economic Affairs.

Titmuss, R. (1962) Income distribution and social change, London: George Allen and Unwin.

Tyrie, A. (2006) One nation again, London: One Nation Group.

Walsha, R. (2000) 'The One Nation Group: A Tory approach to backbench politics or organization, 1950-55', Twentieth Century British History, 11 (2): 183-214.

Walsha, R. (2003) 'The One Nation Group and One Nation Conservatism, 1950-2002', Contemporary British History, 17 (2): 69-120.

h: Iresearch \One Nation\One Nation 100315 20/07/2010 08:45:00 5589 